\title{
VARIATIONS OF PHYSICAL AND CHEMICAL PARAMETERS IN HYPERTROPHIC POND WITHIN PIG SLURRY APPLICATION
}

\author{
R. Kopp, J. Mareš, A. Ziková, T. Vítek
}

Received: November 26, 2007

\begin{abstract}
KOPP, R., MAREŠ, J., ZIKOVÁ, A., VÍTEK, T.: Variations of physical and chemical parameters in hypertrophic pond within pig slurry application. Acta univ. agric. et silvic. Mendel. Brun., 2008, LVI, No. 2, pp. 95-100

During the years 2001 and 2002 we conducted hydrochemical monitoring of intensively managed pond to evaluate the impact of high pig slurry doses on eutrophication. Pig slurry application was carried out in colder period of the year (February-April) via tube system with sludge pump from nearby piggery. Our results showed that pig slurry application do not permanently affect the water quality of Jarohněvický pond. When the correct application is made slurry is effectively utilized by biomass for the growth, which prevents surface and underground waters to be polluted as in the case of incorrect application on agricultural land.

Critical point of this technology in terms of water management is the way of pig slurry application and the exact dose. Even extremely high slurry doses (16.1 kg. $\mathrm{m}^{-2}$ in 2001 and $15.6 \mathrm{~kg} \cdot \mathrm{m}^{-2}$ in 2002) used in Jarohněvický pond did not negatively affected pond ecosystem. Only higher amount of organisms that increased natural fish production was recorded. It is necessary to implement this ameliorative intervention in colder period of the year considering higher hazard of variations in decisive hydrochemical parameters at higher water temperature.
\end{abstract}

pig slurry, fertilization, ponds

The application of pig slurry as a fertilizer is widely used in many countries in order to increase plankton production and fish growth. Manuring is therefore considered to be a cheap way to increase carp production in the pond. Additionally, carp farming could be interested in recycling pig slurry in order to reduce the adverse environmental effect of intensive pig farming (Zoccarato et al., 1995).

Pig slurry is destined for refilling of carbon into water and modification of proportion basic biogenic elements (C, N, P). Negative balance of carbon dioxide in ponds, evoked by plants assimilation at high content of nutrients in water, leads to high values of $\mathrm{pH}$ that could be the cause of fish gill necrosis (Schreckenbach et al., 1975; Sukop, 1980). Bacteria get in water environment with pig slurry as a direct food source of zooplankton (Hartman et al., 1971, 1973; Sukop, 1980). Natural experiments acknowledged positive influence of pig slurry on zooplankton development, especially cladocerans (Sukop, 1979).
Fertilizers batching at doses $0.5-3.6 \mathrm{~kg} \cdot \mathrm{m}^{-2}$ of ponds water increased live weight gain of fish about 30-450 kg.ha-1 (Hartman et al., 1973; Dhawan and Kaur, 2002). Variously high doses of pig slurry were tried in ponds experiments. Pig slurry doses around $1.5 \mathrm{~kg} \cdot \mathrm{m}^{-2}$ were acceptable but they should be applied mainly before vegetation season (Hartman et al., 1973).

Pigslurryapplicationhas onlyshort-terminfluence on water quality. Values describing the high organic pollution are noted immediately after the application. Adequate doses of pig slurry and acceptable form of its distribution to ponds do not cause permanent decline of water quality. Influence on values of physical and chemical parameters in water is not permanent (Blažková et al., 1987).

\section{MATERIALS AND METHODS}

Jarohněvický Pond (area of 95.4 ha) is situated in southern Moravia close to Hodonín town. Kyjovka 
River runs through the pond. Intensive fish farming with carp as a main produced fish is realized in the pond. Values of physical and chemical parameters and quantity of pig slurry applied into pond are presented in the Tables I and II.

I: Quantity of pig slurry applied into Jarohněvický pond

\begin{tabular}{|r|r|r|r|}
\hline \multicolumn{2}{|c|}{2001} & \multicolumn{2}{c|}{2002} \\
\hline Date & $\mathrm{m}^{3}$ & \multicolumn{1}{c|}{ Date } & $\mathrm{m}^{3}$ \\
\hline 28.2. & 1800 & $4-5.3$. & 3916 \\
\hline 1.3. & 1700 & $7-8.3$. & 2906 \\
\hline 5.3. & 1700 & $19-20.3$. & 3678 \\
\hline 13.3. & 1700 & $4-5.4$. & 2200 \\
\hline 19.3. & 1700 & $18-19.4$. & 2000 \\
\hline 27.3. & 1590 & & \\
\hline 10.4. & 1250 & & \\
\hline 11.4. & 1250 & & \\
\hline 20.4. & 1250 & & \\
\hline 29.4. & 1250 & & \\
\hline Total dose & 15190 & & 14700 \\
\hline
\end{tabular}

Water samples were taken from the outlet area of the pond. Samples for chemical analyses were taken into the plastic bottles from the depth of $10-20 \mathrm{~cm}$. Water oxygen saturation, temperature, $\mathrm{pH}$, conductivity and water transparency were measured immediately on the locality. Water oxygen saturation, temperature and $\mathrm{pH}$ were measured by a WTW Oxi 196 dissolved oxygen meter and a WTW pH $196 \mathrm{~T}$ pH meter. Water transparency was determined by the Secchi disc; conductivity measurements were led by Conductivity meter Conmet 1 (Hanna Instruments, USA).

Water samples were transferred into chemical laboratory of Mendel University of Agriculture and Forestry in Brno, where the additional measurements such as an ammonium, nitrates, nitrites, total phosphorus, acid neutralization capacity, chemical oxygen demand, biological oxygen demand and chlorophyll- $a$ concentration were completed.

Ammonium ions $\left(\mathrm{N}-\mathrm{NH}_{4}^{+}\right)$were determined by the Nessler method, nitrite nitrogen $\left(\mathrm{N}_{-} \mathrm{NO}_{2}{ }^{-}\right)$by a method using $\mathrm{N}$-(1-naphthyl)-ethylenediamine, nitrate nitrogen ( $\left.\mathrm{N}-\mathrm{NO}_{3}{ }^{-}\right)$by a method using sodium salicylate, total phosphorus (TP) by a method using ascorbic acid and ammonium molybdenate, acid neutralization capacity (ANC) by a method using hydrochloric acid, chemical oxygen demand (COD) by

II: Values of physical and chemical parameters in pig slurry applied into Jarohnévický pond. (average values from 4 analysis, $\pm S D$ )

\begin{tabular}{|c|c|c|c|c|c|c|c|c|c|}
\hline $\begin{array}{c}\text { Dry } \\
\text { matter } \\
\%\end{array}$ & $\mathrm{pH}$ & $\begin{array}{c}\text { Conductivity } \\
\mathrm{mS} . \mathrm{m}^{-1}\end{array}$ & $\begin{array}{c}\mathrm{ANC} \\
\mathrm{mmol.l^{-1 }}\end{array}$ & $\begin{array}{c}\mathrm{N}^{-\mathrm{NH}_{4}} \\
\mathrm{mg} \cdot \mathrm{l}^{-1}\end{array}$ & $\begin{array}{c}\mathrm{N}-\mathrm{NO}_{3} \\
\mathrm{mg} \cdot \mathrm{l}^{-1}\end{array}$ & $\begin{array}{c}\mathrm{N}^{-\mathrm{NO}_{2}} \\
\mathrm{mg} . \mathrm{l}^{-1}\end{array}$ & $\begin{array}{c}\mathrm{Ca}^{2+} \\
\mathrm{mg} . \mathrm{l}^{-1}\end{array}$ & $\begin{array}{c}\mathrm{TP} \\
\mathrm{mg} . \mathrm{l}^{-1}\end{array}$ & $\begin{array}{c}\mathrm{COD}_{\mathrm{Cr}} \\
\mathrm{mg} . \mathrm{l}^{-1}\end{array}$ \\
\hline $3.6 \pm 0.55$ & $7.4 \pm 0.68$ & $2301 \pm 368$ & $203 \pm 24$ & $3207 \pm 674$ & $27 \pm 7$ & $2.5 \pm 0.9$ & $701 \pm 30$ & $385 \pm 241$ & $17250 \pm 1250$ \\
\hline
\end{tabular}

a method using potassium dichromate and biological oxygen demand (BOD) by the standard diluting method (APHA, 1981). Cyanobacterial and algal biomass was evaluated by chlorophyll-a concentrations using heated ethanol extraction (ISO 10260, 1992). Values of total inorganic carbon (TIC) were deter- mined by arithmetic operation at utilization of water temperature, $\mathrm{ANC}$ and $\mathrm{pH}$.

\section{RESULTS}

Values of hydrochemical parameters are presented in the Tables III, IV and Figure 1.

III: Values of physical and chemical parameters in Jarohnèvický pond within pig slurry application in the year 2001. (Tem. temperature, Con. - conductivity)

\begin{tabular}{|c|c|c|c|c|c|c|c|c|c|c|c|}
\hline Date & $\begin{array}{c}\text { Tem. } \\
{ }^{\circ} \mathrm{C}\end{array}$ & $\begin{array}{c}\text { Oxygen } \\
\%\end{array}$ & $\mathrm{pH}$ & $\begin{array}{l}\text { Con. } \\
\text { mS.m }{ }^{-1}\end{array}$ & 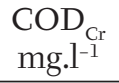 & $\begin{array}{c}\text { ANC } \\
\text { mmol. }{ }^{-1}\end{array}$ & $\begin{array}{c}\mathrm{N}-\mathrm{NH}_{4} \\
\mathrm{mg} \cdot \mathrm{l}^{-1}\end{array}$ & $\begin{array}{c}\mathrm{N}-\mathrm{NO}_{3} \\
\mathrm{mg} \cdot \mathrm{l}^{-1}\end{array}$ & $\begin{array}{c}\mathrm{N}-\mathrm{NO}_{2} \\
\text { mg. } \mathrm{l}^{-1}\end{array}$ & $\begin{array}{c}\text { TP } \\
\text { mg.l-1 }\end{array}$ & $\begin{array}{c}\text { TIC } \\
\text { mg. } \text { l-1 }^{-1}\end{array}$ \\
\hline 28.2 . & 4.0 & above 100 & 8.48 & 84.9 & 42 & 3.30 & 0.50 & 3.70 & 0.200 & 0.030 & 39.7 \\
\hline 9.3. & 5.0 & above 100 & 8.98 & 89.4 & 56 & 3.60 & 2.52 & 3.80 & 0.180 & 0.028 & 42.2 \\
\hline 16. 3. & 7.0 & above 100 & 8.70 & 87.7 & 66 & 3.40 & 2.83 & 3.68 & 0.154 & 0.055 & 40.4 \\
\hline 30.3. & 5.7 & above 100 & 8.78 & 95.0 & 78 & 4.40 & 4.50 & 4.25 & 0.110 & 0.024 & 52.2 \\
\hline 4. 4. & 10.6 & above 100 & 7.67 & 88.9 & 48 & 4.00 & 3.88 & 4.12 & 0.180 & 0.068 & 50.9 \\
\hline 13.4. & 8.4 & 95 & 8.48 & 82.1 & 26 & 3.95 & 3.37 & 3.88 & 0.140 & 0.014 & 47.4 \\
\hline 20.4 . & 8.4 & above 100 & 8.35 & 80.7 & 41 & 3.45 & 3.35 & 3.61 & 0.135 & 0.008 & 41.6 \\
\hline 27.4 . & 11.4 & above 100 & 7.98 & 85.7 & 82 & 3.60 & 4.50 & 3.39 & 0.090 & 0.040 & 44.3 \\
\hline 22.5. & 20.6 & above 100 & 6.83 & 82.3 & 78 & 4.50 & 5.38 & 1.08 & 0.125 & 0.060 & 73.1 \\
\hline
\end{tabular}


IV: Values of physical and chemical parameters in Jarohnévický pond within pig slurry application in the year 2002. (Tem.temperature, Con. - conductivity, Tra. - transparency, Chl-a-chlorophyll-a)

\begin{tabular}{|c|c|c|c|c|c|c|c|c|c|c|c|c|c|c|}
\hline Date & $\begin{array}{c}\text { Tem. } \\
{ }^{\circ} \mathrm{C}\end{array}$ & $\begin{array}{c}\text { Oxygen } \\
\%\end{array}$ & $\mathrm{pH}$ & $\begin{array}{l}\text { Con. } \\
\text { mS.m }{ }^{-1}\end{array}$ & $\begin{array}{l}\text { Tra. } \\
\mathrm{cm}\end{array}$ & $\begin{array}{c}\text { ANC } \\
\text { mmol. }^{-1}\end{array}$ & $\begin{array}{l}\mathrm{N}-\mathrm{NH}_{4} \\
\mathrm{mg} . \mathrm{l}^{-1}\end{array}$ & $\begin{array}{l}\mathrm{N}-\mathrm{NO}_{3} \\
\mathrm{mg} \cdot \mathrm{l}^{-1^{3}}\end{array}$ & $\begin{array}{l}\mathrm{N}-\mathrm{NO}_{2} \\
\mathrm{mg} \cdot .^{-1^{2}}\end{array}$ & $\begin{array}{c}\text { TP } \\
\text { mg. } \text { l-1 }^{-1}\end{array}$ & $\begin{array}{l}\mathrm{COD}_{\mathrm{Cr}} \\
\mathrm{mg} \cdot \mathrm{l}^{-1}\end{array}$ & $\begin{array}{l}\mathrm{BOD}_{5} \\
\mathrm{mg}^{-l^{-1}}\end{array}$ & $\begin{array}{l}\text { Chl-a } \\
\mu g . l^{-1}\end{array}$ & $\begin{array}{l}\text { TIC } \\
\text { mg. } .^{-1}\end{array}$ \\
\hline 26.2 . & 2.4 & 133 & 8.75 & 79.8 & 40 & 4.89 & 0.88 & 3.33 & 0.078 & 0.115 & 48 & 14.0 & 45.39 & 58.2 \\
\hline 5.3. & 4.4 & 162 & 8.74 & 79.9 & 35 & 4.53 & 1.09 & 3.59 & 0.068 & 0.392 & 50 & 16.9 & 48.60 & 53.9 \\
\hline 12.3. & 7.2 & 63 & 8.38 & 90.4 & 30 & 5.49 & 19.58 & 3.26 & 0.176 & 0.838 & 90 & 25.0 & 42.72 & 66.2 \\
\hline 20.3. & 7.4 & 146 & 8.18 & 89.9 & 30 & 5.25 & 9.00 & 3.07 & 0.140 & 0.907 & 88 & 31.4 & 24.56 & 64.0 \\
\hline 26. 3. & 2.8 & 111 & 8.59 & 87.1 & 40 & 5.01 & 8.23 & 3.00 & 0.112 & 0.790 & 70 & 20.5 & 61.41 & 60.0 \\
\hline 2. 4. & 11.7 & 277 & 8.87 & 76.7 & 40 & 3.46 & 2.43 & 3.25 & 0.094 & 0.410 & 67 & 15.0 & 38.71 & 40.7 \\
\hline 9.4. & 7.7 & 141 & 8.80 & 81.0 & 30 & 4.05 & 3.21 & 2.62 & 0.116 & 0.568 & 103 & 33.0 & 34.71 & 47.9 \\
\hline 17.4. & 11.1 & 189 & 8.85 & 77.0 & 30 & 3.64 & 0.84 & 2.55 & 0.106 & 0.635 & 97 & 26.4 & 60.88 & 42.8 \\
\hline 22.4 . & 13.4 & 58 & 7.80 & 81.9 & 20 & 3.99 & 8.27 & 1.74 & 0.190 & 0.915 & 119 & 25.3 & 80.10 & 49.8 \\
\hline 30.4 . & 15.5 & 93 & 8.06 & 78.2 & 30 & 3.46 & 3.82 & 1.38 & 0.163 & 0.545 & 77 & 24.9 & 77.43 & 42.2 \\
\hline
\end{tabular}

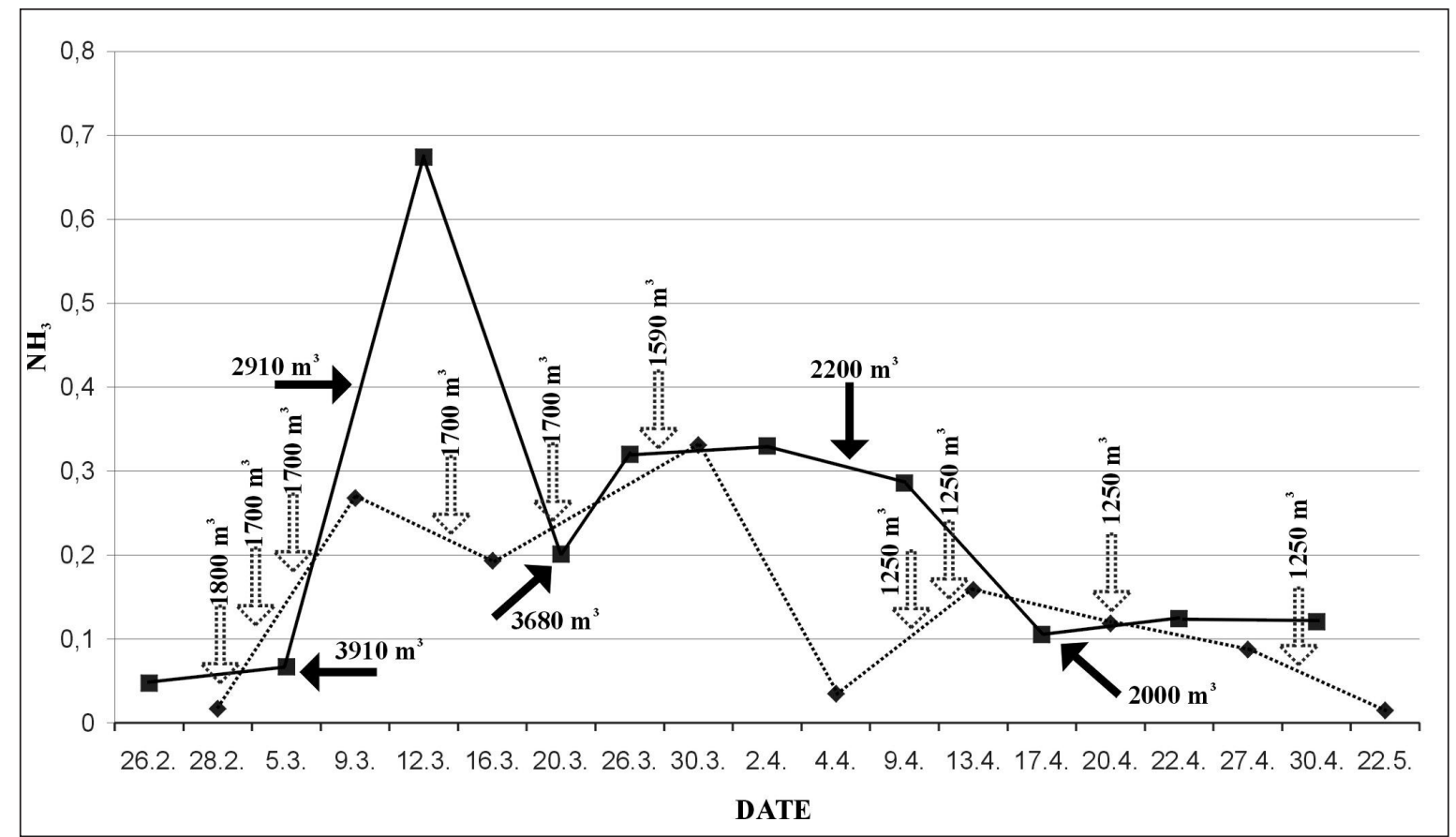

1: Values of toxic ammonia $\mathrm{NH}_{3} m g . l^{-1}$ (line) and individual doses of pig slurry (arrow) in the year 2001 (dotted line and arrow) and 2002 (solid line and arrow)

Pig slurry of total quantity $15190 \mathrm{~m}^{3}$ in the year 2001 was applied into Jarohněvický pond in ten doses from 28.2. to 29.4. Pig slurry of total quantity $14700 \mathrm{~m}^{3}$ in the year 2002 was applied into Jarohněvický pond in five doses from 4.3. to 19.4 (Fig. 1).

\section{DISCUSSION}

Low water temperature $\left(2.4-15.5^{\circ} \mathrm{C}\right)$, relatively (in term of toxic ammonia) low values of $\mathrm{pH}$ (7.67-8.98) and sufficiency of dissolve oxygen (58-277\%) kept off dramatic increase in value of toxic ammonia within pig slurry application (Fig. 1). High values of ammonia are the greatest danger to aquatic organisms within pig slurry application.

The highest measured value of ammonium ions $\left(\mathrm{N}-\mathrm{NH}_{4}\right)$ was $19.58 \mathrm{mg} . \mathrm{l}^{-1}$ and we can calculate values of toxic ammonia $\left(\mathrm{NH}_{3}\right) 0.67 \mathrm{mg} . \mathrm{l}^{-1}$ that make provision for $\mathrm{pH}$ and water temperature. Maximum permissible concentration of $\mathrm{NH}_{3}$ for cyprinids is only $0.05 \mathrm{mg} . \mathrm{l}^{-1}$. Values around 1-1.5 mg. $\mathrm{l}^{-1} \mathrm{NH}_{3}$ were lethal to a half of the fish stock during 48 hours (Svobodová et al., 1987).

Most of ammonia nitrogen values measured in the pond and water inflow were higher than the maximum permissible concentration, but only in a short-term duration, mostly immediately after 
pig slurry application. Pond ecosystem quickly degrades toxic ammonium by primary producers without negative influence on fish stock.

The values of organic compounds were also higher in the pond water. Blažková et al. (1987) mentioned increasing values of BOD after application of pig slurry. Increase of values is depending on water sampling interval after pig slurry application. BOD values of Jarohněvický pond were at interval 14-33 mg. $\mathrm{l}^{-1}$ and conform to high doses of pig slurry that were applied. It is possible to expect decrease of $B O D$ values during a longer time.

After the first doses of pig slurry application, COD values increased. Measured values of COD were comparable with eutrophic ponds of the same area without application organic fertilizers (Kopp, 2006).

Pig slurry is used especially to supplement carbon into water. High assimilation of plants makes carbon to be a limiting element for another production. This situation is common especially in ponds with intensive fish management (Sukop, 1980). In the case of Jarohněvický pond, the limiting element was phosphorus in the year 2001. Phosphorus quantity was low in water outlet despite of pig slurry application. The quantity of nitrogen and carbon were high in the year 2001 therefore these elements were not limiting for another production.

The year 2002 in comparison with the year 2001 showed markedly higher quantity of phosphorus in water inflow. Average value of phosphorus in water inflow was $0.28 \mathrm{mg} . \mathrm{l}^{-1}$ in the year 2001 and $0.60 \mathrm{mg} . \mathrm{l}^{-1}$ in the year 2002. Imperfect cleaning of sewage water from the town agglomeration caused high values of phosphorus. The phosphorus was not the limiting element in the year 2002 during application pig slurry however nitrogen or carbon was limiting for another production.

The effect of organic fertilizers from animal breeding farm is higher in ponds with polycultural fish stock where is the highest weight-gain per fish
(Buck et al., 1978; Dhawan and Kaur, 2002; Zoccarato et al., 1995). The chicken slurry is the most suitable (Kangombe et al., 1995). Hartman et al. (1973) mentioned doses of pig slurry $0.5-2.0 \mathrm{~kg} . \mathrm{m}^{-2}$ of ponds water that increased live weight gain of fish about 30-450 kg.ha-1. Woynarovich (1976) reported pig slurry conversion of 3-5\% into fish body mass. In the case of polycultural fish stock is ratio higher than in the case of carp monoculture. Zhu et al. (1990) mentioned demand of $8.3 \mathrm{~kg}$ dry weight of pig slurry to weight-gain of $1 \mathrm{~kg}$ fish flesh.

Jarohněvický pond had concentrate polycultural fish stock during the experiment and fish were intensively fed by cereals. Total production of the pond was 110-125 tons. Production from supplementary fish food was 65-75 tons. Natural production of the pond supported by pig slurry was 45-50 tons (470-520 kg.ha-1). In this experiment the fish production in the high fertilized pond appears the same values that obtained other researchers.

\section{CONCLUSION}

Even extremely high slurry doses $\left(16.1 \mathrm{~kg} \cdot \mathrm{m}^{-2}\right.$ in 2001 and 15.6 kg.m-2 in 2002) used in Jarohněvický pond did not negatively affected pond ecosystem. Only higher amount of organisms that increased natural fish production was recorded. Total annual fish yield from this experimental pond was 110-125 tons (1150-1310 kg.ha-1). This high fish harvest exceeded average values of fish production values $\left(465 \mathrm{~kg} \cdot \mathrm{ha}^{-1}\right)$ in the Czech Republic (Ženíšková and Galll, 2007).

It is necessary to implement this ameliorative intervention in colder period of the year considering higher hazard of variations in decisive hydrochemical parameters at higher water temperature. Unsuitable influence of high single doses on hydrochemical parameters is evident by comparison the year 2001 (10 doses) and the year 2002 ( 5 doses). Especially values of toxic ammonia were fundamentally higher in the year 2002 than in the year 2001.

\section{SOUHRN}

\section{Změny fyzikálních a chemických parametrů hypertrofního} rybníka po aplikaci prasečí kejdy

V letech 2001 a 2002 jsme prováděli hydrochemické sledování intenzivně obhospodařovaného rybníku pro posouzení eutrofizačního vlivu vysokých dávek prasečí kejdy. Aplikace prasečí kejdy byla realizována v chladnějším období roku (únor-duben) z nedaleké výkrmny prasat za pomocí potrubního systému s kalovými čerpadly.

Naše výsledky ukázaly, že kejdováním Jarohněvického rybníka nedochází k trvalému ovlivnění jakosti vody. Kejda je při správné aplikaci účelně využita k nárůstu biomasy a nestává se zdrojem znečištění povrchových nebo podzemních vod, k čemuž často při nevhodném způsobu aplikace na zemědělské pozemky dochází.

Kritickým místem celé této technologie zůstává z vodohospodářského hlediska způsob aplikace kejdy a výše jejích dávek. Přes extrémně vysoké dávky (16,1kg.m²-2 v roce 2001 a 15,6kg.m-2 v roce 2002) použité v Jarohněvickém rybníce se s nimi ekosystém rybníka vyrovnal zvýšeným biologickým oživením, což se žádoucím způsobem projevilo na zvýšení přirozené rybí produkce. S ohledem na riziko nárazových výkyvů rozhodujících hydrochemických parametrů rybničního prostředí především 
při vyšších teplotách vody je nutné omezit aplikaci tohoto melioračního zásahu na chladnější období roku a výši dávek kejdy snížit u rybníků s kolísavým pH vody.

prasečí kejda, hnojení, rybníky

This study was supported by the Research plan No. MSM6215648905 "Biological and technological aspects of sustainability of controlled ecosystems and their adaptability to climate change", which is financed by the Ministry of Education, Youth and Sports of the Czech Republic.

\section{REFERENCES}

APHA, 1981: Standard methods for the examination of water and wastewater ( $15^{\text {th }}$ edn) American public Health Association Inc., Washington D.C.

BLAŽKOVÁ, D., KOČKOVÁ, E., ŽÁKOVÁ, E., 1987: Vliv aplikace kejdy na vývoj kvality vody v rybnících. In: Intenzifikace rybárské výroby a kvalita vody. Velké Meziřǐčí 8.-9. prosince 1987, s. 56-61

BUCK, D. H., BAUR, R. J., ROSE, C. R., 1978: Utilization of swine manure in a polyculture of Asian and North American fishes. - Trans. Amer. Fish. Soc. 107, 1: 216-222

DHAWAN, A., KAUR, S., 2002: Effect of pig dung on water quality and polyculture of carp species during winter and summer. - Aquacult. Int. 10 (4): 297-307

HARTMAN, P., LAVICKÝ, K., ČERVINKA, S., POKORNÝ, J., KRONIKA, V., 1971: Využití drůbeží a prasečí kejdy ke hnojení rybníkù. - Dílči zpráva výzk. úkolu Stát. rybářství Č. Budějovice

HARTMAN, P., LAVICKÝ, K., ČERVINKA, S., POKORNÝ, J., KOMÁRKOVÁ, J., REICHARD, S., 1973: Použití prasečí kejdy ke hnojení rybníků. Závěrečná zpráva vízk. úkolu. Státní rybářství Č. Budějovice, $24 \mathrm{~s}$.

ISO 10260: Měření biochemických ukazatelů Spektrofotometrické stanovení koncentrace chlorofylu-a. 1995, Praha, 12 s.

KANGOMBE, J., BROWN, J. A., HALFYARD, L. C., 1995: Effect of using different types of organic animal manure on plankton abundance, and on growth and survival of Tilapia rendalli (Boulenger) in ponds. - Aquaculture, 130 (1):51-65

KOPP, R., 2006: Phytoplankton of the Zámecký Pond. Czech Phycology, 6: 111-125, ISSN 1213-3434

SCHRECKENBACH, K., SPANGENBERG, R., KRUG, S., 1975: Die Ursache der Kiemennekrose. Z. Binnenfischerei 12, 9: 257-288

SUKOP, I., 1979: Vliv použití tekutých organických hnojiv v různých typech plůdkových rybníků na rozvoj jejich přirozené potravy. - Kand. dis. práce, VŠZ Brno

SUKOP, I., 1980: Vliv aplikace drůbeží kejdy a cereritu na rozvoj zooplanktonu plůdkových výtažníků. - Živočišñá výroba 25, 11: 847-855

SVOBODOVÂ, Z. (eds.), 1987: Toxikologie vodních živocichir. SZN Olomouc, $232 \mathrm{pp}$.

WOYNAROVICH, E., 1976: The possibility of combining animal husbandry with fish farming, with special reference to duck and pig production. FAO Techn. Conf. Aquacult., Kyoto, Japan, R6: 11 s.

ZHU, Y., YANG, Y., WAN, J., HUA, D., MATHIAS, J. A., 1990: The effect of manure application rate and frequency upon fish yield in integrated fish farm ponds. Aquaculture, 91 (3-4): 233-251

ZOCCARATO, I., BENATTI, G., CALVI, S. L., BIANCHINI, M. L., 1995: Use of pig manure as fertilizer with and without supplement feed in pond carp production in Northern Italy. - Aquaculture 129, 1-4: 387-390

ŽENÍŠKOVÁ, H., GALL, V. (eds.), 2007: Situační a výhledová zpráva ryby. MZ Praha, 41 pp.

Address

Ing. Radovan Kopp, Ph.D., Doc. Dr. Ing. Jan Mareš, Ing. Andrea Ziková, Ing. Tomáš Vítek, Ph.D., Oddělení rybářství a hydrobiologie, Mendelova zemědělská a lesnická univerzita v Brně, Zemědělská 1, 61300 Brno, Česká republika, kopp@mendelu.cz,mares@mendelu.cz,xzikoval@node.mendelu.cz,gabon@centrum.cz 
